Article

\title{
Relationships among Country Image, Tour Motivations, Tour Quality, Tour Satisfaction, and Attitudinal Loyalty: The Case of Chinese Travelers to Korea
}

\author{
Jinsoo Hwang $\left.{ }^{1} \mathbb{(}\right)$, Muhammad Asif ${ }^{2} \mathbb{D}$ and Kwang-Woo Lee ${ }^{3, *}$ \\ 1 The College of Hospitality and Tourism Management, Sejong University, 98 Gunja-Dong, Gwanjin-Gu, \\ Seoul 143-747, Korea; jhwang@sejong.ac.kr \\ 2 School of Public Affairs, Zijingang Campus, Zhejiang University, Hangzhou 310058, China; \\ asif.ma015@gmail.com \\ 3 Department of Tourism Management, College of Economics and Business Administration, Daegu University, \\ 201, Daegudae-ro, Gyeongsan-si, Gyeongsangbuk-do 712-714, Korea \\ * Correspondence: kw.lee@daegu.ac.kr
}

Received: 9 March 2020; Accepted: 9 April 2020; Published: 15 April 2020

\begin{abstract}
This study examined the antecedents and the consequences of tour motivations. More specifically, this study proposed how two sub-dimensions of a country's image, such as the cognitive and the affective destination images, affect tour motivations. In addition, it was proposed that tour motivation helps to enhance tour quality and tour satisfaction. Lastly, this study examined the effect of tour quality the tour satisfaction on word-of-mouth. A total of 623 samples were employed in order to test the seven hypotheses. This study employed the AMOS program to conduct confirmatory factor analysis and structural equation modeling. The results of the data analysis showed that the cognitive and the affective destination images play an important role in the formation of the tour motivation. This study also found that tour motivation has a positive influence on tour quality. Additionally, the current study confirmed the effect of tour quality on tour satisfaction. Lastly, the influences of tour quality on tour satisfaction and word-of-mouth were identified.
\end{abstract}

Keywords: country image; tour quality; attitudinal loyalty; tour satisfaction; tour motivations; word-of-mouth; Korea; Chinese tourists

\section{Introduction}

In the most recent decade, mainland Chinese tourists have developed into one of the more significant markets in outbound tourism. The number of mainland Chinese outbound travelers has phenomenally grown reaching 166 million people in 2019 [1], and they spent almost US\$ 277 billion in 2018. In view of its unmistakable financial development and continuous diminishing use of visa controls, China has seen a massive development of its outbound travel industry. In 2004, mainland Chinese outbound travel moved closer to 29 million, and the number expanded to 131 million in 2017 [2]. The number of Chinese outbound tourists began to increase in May 1991 when the Chinese government made travel guidelines less stringent for the first time for its residents. Furthermore, the government declared a 5-day work week in March 1995 for Chinese laborers. This has empowered numerous Chinese to find time to vacation outside of China for a quick getaway. The advancement of the economy and the resulting affluence that it has generated have enabled the Chinese to enjoy a better quality of living and greater prosperity [3]. As a result, it is advantageous for Korea to utilize its promotion and marketing endeavors to pull in travelers from China. To accomplish this, it is essential to understand the country's image and what motivates the Chinese tourists. 
The global tourism industry has become progressively more profitable and more competitive, so the vast majority of destination marketing organizations (DMOs) have concentrated their endeavors on explicitly creating a better destination image in order to be more appealing in the psyches of the potential tourists, since the travel industry is one of the segments that provide the biggest contributions to the financial improvement of a country [4]. If the destinations inside a country are the spots that are known and favored by international travelers, it will impact the regional development and improve the nation countrywide. Since the destination's image influences the tourists' basic decision-making process and travelers' opinions in connection to a specific travel destination, it is along these lines that a country must show a positive image to the potential travelers [5].

When examining the behavior of a tourist, the tourist motivation can be viewed as the essential factor [6,7]. A push-pull model for travel motivation was created by Crompton [8], which recognized the push-and-pull consequences for a traveler's destination decision and experience. As indicated by this model, the push power motivates a traveler to venture out from their home and look for some undefined getaway destination, and the pull power forces a traveler toward specific destinations that are seen as appealing on account of their characteristics $[9,10]$. A few researchers have expressed that the motivation is identified with the affective part of the image, and a person's affective image for a destination is affected by the traveler's motivation, which is centered upon their past travel encounters [11-13]. In the previous tourism literature, numerous researchers recognized the significance of understanding better the relationship of variables, such as travel motivation, destination image, visitor satisfaction, revisit intentions, and intention to recommend [14-20]. However, few examinations utilized both the cognitive and the affective parts to understand the overall image of a destination [21-24]. The treatment of the cognitive and the affective components separately is important to look at their one-of-kind effects on the travelers' motivational structure and the future practices [22,25-27].

This investigation analyzed the connections between a country's image and the tour motivation, which includes tour quality, tour satisfaction, and word-of-mouth. Therefore, this research: (1) tried to give a better comprehension of the elements motivating tourists from China to travel to the Republic of Korea by analyzing the connection between a country's image and the motivation; (2) examined the relationship among the tour motivation with the tour quality and the tour satisfaction; and (3) investigated the influences of the tour quality on the tour satisfaction and the word-of-mouth and the effects of tour satisfaction on word-of-mouth. Exploring the motivations that affect an individual's destination determination would empower one to foresee their future travel patterns, which would thereby help to develop more progressively fitting market strategies to draw them in [15].

This research is expected to add to the literature by breaking down the country image inside the evaluation of an image, which can help assist the governmental agencies of the Republic of Korea by distinguishing the qualities and the shortcomings of their destination, anticipating tourists' behavioral intentions, and giving invaluable insights into managing and developing tourist destinations. This study presents a profound review of the literature and a confirmation of new measurement tools. This examination also presents a hypothetical foundation to distinguish between the cognitive and the affective segments of a country's image, and it distinguishes between the different elements of every one of these elements.

\section{Literature Review}

\subsection{Motivation}

Motivation can be characterized as a condition or an inspiration that leads individuals to embrace particular conduct with the aim of fulfilling their needs [28]. The motivation is concerned with understanding a tourist's conduct and the process of choosing a destination $[29,30]$, because motivation is the force that drives all acts $[8,31]$.

There can be a string of pull and push factors that can impact the travel and destination determination. The push elements are the inherent socio-psychological driving force, such as 
getting away from routine environments, finding ways to unwind, and escaping from repetitive social interactions [32]. The pull element is the engaging quality that attracts tourists to visit a destination [33]. Internal (push) and external (pull) motivations are also distinguished in the decision to take a journey [8,29]. The internal motivations incorporate the longing to escape, rest, maintain a good reputation, have good health and physical care, experience adventure, and have social interactions. It very well may be portrayed as internally created desires, because the traveler looks for signs in things and creates events that contain the guarantee of lessening the traveler's common desires [34]. A tourist's cognitive processes and travel motivations are part of the push elements, which may include socialization, finding new things, looking for a fun new experience, satisfying dreams, or fulfilling the need to break out of daily schedules [35]. In contrast to the latter are the external motivations that depend on the engaging quality of the destination. The pull factors are those that arise because of the engaging quality of a destination that is seen by those with the affinity to travel. The push factors have been viewed as beneficial to clarify the longing for travel, while pull motivations have been employed to clarify the decision for the travel destination [8].

Six factors were determined for the travel motivations of Hong Kong residents by Ap and Mok [36], which included individual/social satisfaction, touring, new experiences, relaxation, prestige, and having connections with others. In another research, Jang et al. [37] explored the travel motivations of Japanese tourists to North America, and they found that they could be grouped into two categories that included novelty/nature seekers and escape/relaxation seekers. Regardless of not being unified in the literature, various elements of motivations have been recognized, including intellectual motivations, escape and relaxation, belonging, enthusiasm and social adventure, and prestige $[16,21,38]$. A portion of the results demonstrates the potential possibilities of the explicit motivational components related to the close positive relationships with the explicitly perceived destination image components. In congruence with the conclusions of the investigation, there is a close connection between tourists' motivation and their destination's perceived image. The motivation is the principle factor that gives weight in the image formation model $[39,40]$. Moutinho [41] hypothesized that motivations assume a significant role in the destination image formation in a conscious or unconscious manner due to the influence of the psychological motivations on the image of the destination.

A person's choice to travel might be sparked by various reasons, and these reasons can be seen as the motivation. Recognizing tourist motivations is a key component in marketing, due to their impact on the way in which they pick a destination [38] and on their behavior. In any case, this distinguishing proof represents some problems, since the purchasing procedure is not activated by just a single thought process or motive, but rather includes a few interrelated motives [42].

Recently, the released figures on outbound tourists from China showed that 142.7 million people travelled, which was a positive upward swing of 58\% over that same reported period in 2012. In 2018, a report conducted on the developing Chinese outbound travel market found that the most prevalent destinations visited by the mainland Chinese were Hong Kong, Macau, Taiwan, Thailand, Japan, Vietnam, and the Republic of Korea. To encourage and successfully draw in the Chinese mainlanders, it is imperative to understand the Chinese outbound traveler better. Regardless of the increasingly strong global interest in Chinese outbound travelers, the Chinese market, and the significance of understanding the Chinese mainlanders, recent studies have not done enough in their research to identify the shared traits and the differences as far as their attributes, their country image of Korea, and their motivation. However, a significant issue emerges here, which brings up the following question. What is the effect of the image on tour motivation? It is important to break down the impact of the travel arrangement on the hypothetical association with the country image, the tour motivation, and the tourists' fulfillment. This investigation makes an initial step in bridging the gap in the literature by examining the Chinese mainlanders' apparent opinion about the image and the motivation with regards to South Korea. 


\subsection{Country Image}

The image can be characterized as the outflow of all the tangible information, biases, imaginations, impressions, and emotional musings regarding how an individual or a group makes a decision about a specific destination $[43,44]$. The image is also produced from a mental process by people who make a mental portrayal of any particular destination from their previously acquired knowledge about that destination [12,45]. Because the images are the generalization of an enormous number of affiliations and snippets of data associated with the destination [46,47], the images held by the potential tourists are very significant in the destination choosing process. In addition, the image is the basic factor to achieve success in the destinations travel industry development [48].

In the tourism industry, it is commonly understood that the travel industry destination image includes the cognitive and the affective interpretations of the images. A person's cognitive assessments are their very own knowledgeable insight and convictions about an item. The cognitive image is typically identified with tangible characteristics, such as nature, culture, and experiences. The affective evaluations are identified with a person's sentiments towards the item, which may produce the feelings of stimulation, energization, pleasure, and relaxation $[14,21,49,50]$.

The tourists' cognitive portrayal of a country is called the country image [51]. Martin and Eroglu [52] characterized the country image as the aggregate of all distinct, inferential, and informational beliefs someone has about a specific country $[53,54]$. The country-of-origin image alludes to the general impression of a country that is present in a traveler's psyche as expressed by its way of life, political framework, and the level of economic and industrial development. Most of the recent studies about the country image have focused on the cognitive part of the country image more than on the affective aspects of a tourist's emotions toward a country. There has been very little research about what impacts the creation and the structure of this image. Echtner and Ritchie [55] proposed qualities separated into areas that identified with the particular attributes of the surrounding areas of a destination, such as the kind disposition of the locals of a destination and the beauty of the city. Several researchers expressed that the motivation is identified with the affective part of an image, and a person's affective image for a destination is impacted by the traveler's motivation, which is dependent on their past travel experiences $[11,12,56,57]$. However, some other examinations [22] concluded that a larger impact on the overall image was due to the cognitive part. Interestingly, Baloglu and McCleary [21] explained that for the regions that previously had a greater negative image and for those areas that have not been recently visited, the affective image may have a more prominent weight. Kim and Yoon [49] showed that for a developing country, the affective image has a greater weight on the overall image construct.

The cognitive country image speaks to the tourists' convictions about a country's industrial development, standard of living, degree of economic development, and its technological achievements, while the affective country image represents the travelers' feelings about a country due to its government, policies, and its culture and people [51,58,59]. The cognitive and affective country image will impact a tourist's judgment in unexpected ways. Distinguishing between an affective and a cognitive country image makes it possible to intently analyze the relative impact of tourists' thinking about, and the emotions toward, a country. The cognitive and the affective dimensions are both part of a country's image [58-60]. It is essential to differentiate between the cognitive and the affective image, since tourists regularly have incongruent cognitive and affective reactions towards the same country. Substantial observational research on cognitive and affective images found that the destination image is a multidimensional concept that involves both of those interrelated elements [21,25,61]. The overall image of a destination is a subsequent level construct shaped by a cognitive and an affective component [62]. The cognitive and the affective images are attributes that impact a tourist's motivation [63]. At the point when tourists experiences their destination, the primary degree of reaction is emotional and this affective quality ascribed to a destination rules the resulting directions and the actions toward that place $[64,65]$. 
In spite of the fact that it is claimed that cognitive and affective elements are progressively correlated to frame a destination image $[12,66]$, it is feasible that each cognitive and affective image element could individually contribute to the overall image development [38]. With regards to the previous tourism literature, Baloglu and McCleary [21] and Stern and Krakover [67] suggested empirically that these cognitive and affective assessments directly impact the overall image. It is recommended that every segment and overall image ought to be measured independently to more readily comprehend the relationships between them [68]. Consequently, it is critical to better understand the tour motivations that tourists credit to their destination and what image measurements of a destination animate this country's image. Thus, the following hypotheses are presented:

Hypothesis 1 (H1): Cognitive destination image positively affects tour motivations.

Hypothesis 2 (H2): Affective destination image positively affects tour motivations.

\subsection{Tour Quality}

The tour quality is the outcome of the level of congruence between the tourists' desires and the expected prerequisite activities in the natural settings of the tour offering [10]. According to Chen and Tsai [28] characterized tour quality as the traveler's evaluation of the service delivery procedure in relationship with the tour experience. Parasuraman et al. [69] proposed that the quality of a company's provided service is to quantify the consumer's impression of the quality. Along these lines, the perceived quality is characterized as the customer's judgment about a tour association's general worth and quality [70]. Specifically, the available experience can be mostly defined as the perceived travel quality centered on the semblance between the anticipation and the real performance [28].

The Chinese tourists judge against previous expectations for service arrangement and how they felt with their post-experiences, and they decide the tour quality along these lines. Because of their earlier expectations, they are significantly vulnerable to the impact of the reference groups and stick to the social standards [71]. Tourist motivations are identified with the past experiences or the impressions of the previous tourists that went to a destination. The tourist motivations may affect the positive assessments of the tour quality once the tourists are keen on or have great encounters with their tours destination. The past descriptions propose that motivations might be determinants of the tour quality [72].

As indicated by the study by Lee, Jeon and Kim [72], this investigation should be a significant instrument for the local tourism specialists who intend to pull Chinese tourists to Korea; it should aid the specialists in looking at the present state seriously and setting up plans for what is to come. The key destination characteristics influencing the tour quality that are probably going to be alluring for the outbound Chinese tourists are security, delightful scenery, well-prepared tourism facilities, distinctive cultural/historical assets, and good weather [73]. How a tourist feels about these key qualities will greatly impact their choice about whether to visit Korea. In light of the literature review, the following hypothesis is proposed:

Hypothesis 3 (H3): Tour motivations positively affect tour quality.

\subsection{Tour Satisfaction}

Tourism satisfaction is characterized as the degree of general delight or the contentment felt by a traveler. The traveler's overall contentment or pleasure arises due to the capacity of the traveling experience to satisfy the traveler's anticipations, desires, and needs relative to the excursion [28]. Baker and Crompton [74] have characterized satisfaction as an affective condition of the tourist, which is reached after experiencing a tour. Spreng et al. [75] argue that the experienced quality is the result of the satisfaction that the visitor had experienced. According to Parasuraman et al. [76], the greater 
levels of perceived service quality give rise to higher customer satisfaction. Despite the fact that the tourism experience is temporary and is not simple [77-79], if the traits of tourism fulfill the traveler's needs, the traveler would have positive experiences at that point. The research by Lee, Jeon and Kim [72] concluded that the tour quality influences the tourist satisfaction. Cronin Jr and Taylor [80] also proposed that quality is an antecedent regarding satisfaction. The tourist satisfaction is a positive discernment or feeling that travelers create or gain by taking part in recreational activities, and it is communicated as the level of pleasure that was created from these types of encounters [81]. At the point when execution surpasses desires, the affective satisfaction is often the outcome. Generally, the tourist satisfaction decidedly corresponds with the quality of the travel sites encountered [82]. Ultimately, the tourist satisfaction is imperative to management, since it impacts the traveler's choice regarding a destination $[17,83,84]$ and future behaviors [19,85-87].

The empirical investigations of motivation in tourism have been shown to greatly contribute to the tourist satisfaction in different settings, such as sightseeing tourism [88], cultural festivals [89], and farm resorts [90]. The Chinese tourist's satisfaction can be developed by the tour qualities of lovely scenery, historical heritage sites, several souvenir shops, and local items. According to Yoon and Uysal [87], the push motivation did not meaningfully impact satisfaction, but the pull motivation straightforwardly and contrarily influenced satisfaction. The improvement of the tourism satisfaction model is critical concerning the management of the travel agents or drawing travelers to Korea. In order to advance the satisfaction of Chinese tourists, Korean travel advertisers ought to primarily concentrate both on expanding tourist motivations and cultivating the tour quality in Korea. The expansion in tourist motivations and quality would for the most part initiate increments in advertising and administration costs. No exact investigations on the Chinese outbound travelers have analyzed the causal connections between the tourist motivation and satisfaction for Korean tourism. Accordingly, analyzing whether the above causal connections exist in the proposed model applied to tourism in Korea is fascinating, since a sustainable tourism industry will contribute tremendously to Korea's economic and social prosperity. Logically, this leads to the following hypotheses:

Hypothesis 4 (H4): Tour motivations positively affect tour satisfaction.

Hypothesis 5 (H5): Tour quality positively affects tourist satisfaction.

\subsection{Word-of-Mouth}

The readiness of the tourism customers to suggest and recommend travel destinations and participate in positive word-of-mouth scenarios enables the tourism administrators to evaluate their administration strategies and techniques. The tourism research has concerned itself with whether the future tourist behavior can be anticipated from the tourist satisfaction model [83]. Along these lines, satisfaction is viewed as a precursor variable of the word-of-mouth $[91,92]$. The word-of-mouth (WOM) is characterized as "casual, individual-to-individual correspondence between an apparent non-business communicator and a recipient with respect to a brand, an item, a business, or a service" $[10,93]$. An individual with a perceived positive image and satisfaction will more often recommend a destination $[22,85,94,95]$. Therefore, it is normal that a guest with a positive tour quality and generally positive image as an overall impression of the cognitive and the emotional image would be likely to return to the destination and endorse it to other people. The tourist satisfaction brings about larger quantities of fulfilled tourists returning to and endorsing more destinations [10], which thus advances the sustainable improvement of tourism, especially in management and advertising [96-98].

The tourist satisfaction is a primary factor of tourist future behaviors [10]. There is a wide understanding among researchers who consider the significant positive relationship between the tourist satisfaction and the intentions to return to the destinations [38,99]. For example, if a guest is to a great extent satisfied with a specific destination, they will probably desire to revisit it again 
and be glad to endorse it to their colleague or relatives [100]. Jones and Sasser [101] suggested that getting the message out by WOM is a critical type of consumer behavior for any organization. WOM was distinguished as one of the most significant factors to estimate the customer devotion for practically all enterprises. Day and Landon [102] suggested that WOM correspondence demonstrates the classic instances of private behavior. There has been an extraordinary assemblage of studies that concentrated on the relationship between quality, satisfaction, and behavioral intention [74,103]. Subsequently, quality and satisfaction all have been demonstrated to be the main indicators of the future behavioral intentions [5,74,103-106]. By examining the connections between the future behavioral intentions and its determining factors, the destination tourism administrators would understand better how to develop an attractive image and their promoting endeavors in order to make the most of their utilization of their available resources [28]. Thus, we propose the following hypotheses:

Hypothesis 6 (H6): Tour quality positively affects word-of-mouth.

Hypothesis 7 (H7): Tour satisfaction positively affects word-of-mouth.

\subsection{Proposed Model}

The following research model is proposed based on the seven hypotheses as shown in Figure 1.

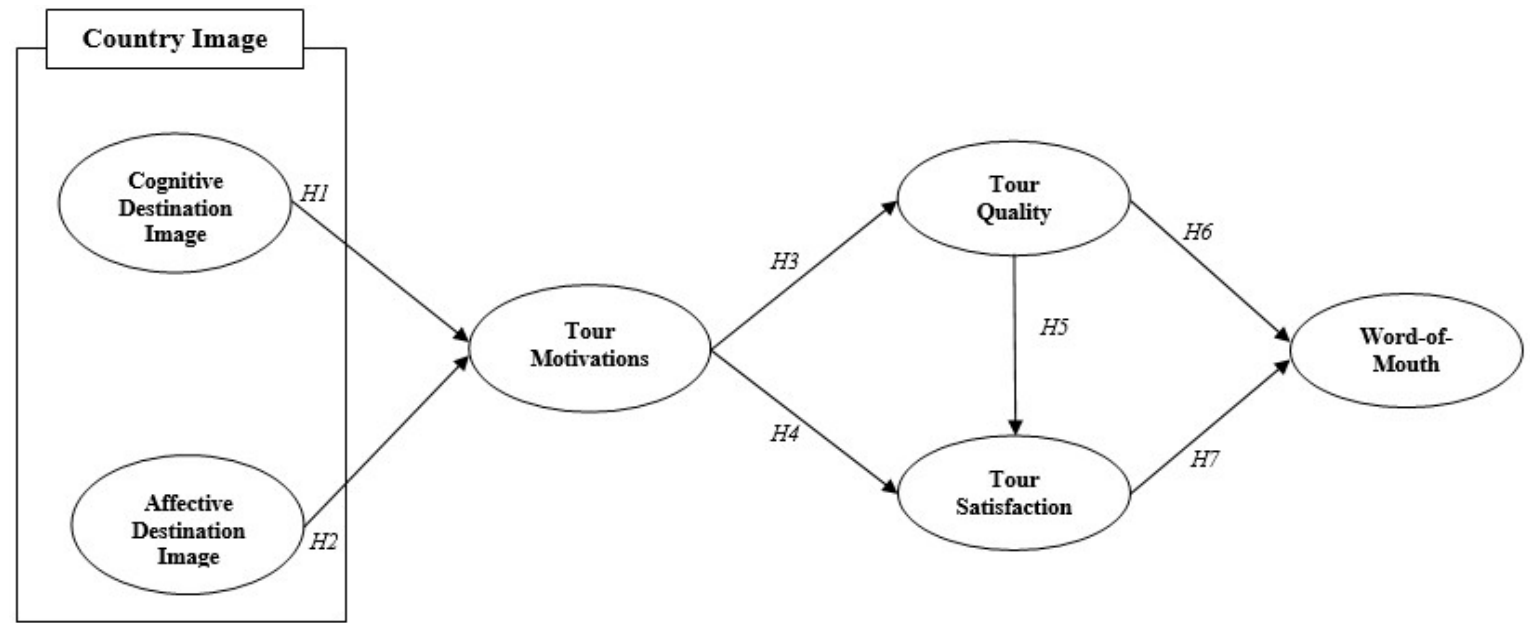

Figure 1. Proposed conceptual model.

\section{Methods}

\subsection{Measures}

First, the two sub-dimensions of a country's image, which include the cognitive and the affective destination images, were measured using eight measurement items from Laroche, Papadopoulos, Heslop and Mourali [58] and Li et al. [107]. Second, the tour motivations were measured using three measurement items cited from Tang [108]. The tour quality was measured with three measurement items used from Hwang and Lee [109]. The measures for the tour satisfaction were derived from Hwang and Lee [110] and Lee, Jeon and Kim [72]. Lastly, the word-of-mouth was derived from Hennig-Thurau et al. [111] and Zeithaml [70]. All of the items were measured employing a five-point Likert scale, which ranged from $1=$ strongly disagree to $5=$ strongly agree.

\subsection{Data Collection}

This study conducted an online panel survey method in order to collect the data using an online panel survey company in China. The first question in the survey was used to check whether the respondents have visited South Korea within the past twelve months. If the respondent answered yes, 
the survey continued. If the respondent answered no, the survey ended. A total of 1000 panels joined the survey. Among them, only 623 samples were used for further analysis, because of missing data and a Mahalanobis distance check.

\subsection{Descriptive Statistics}

The sample $(n=623)$ had a total of $57.3 \%$ females $(n=357)$. The mean age of the respondents was 32.85 years old. The highest education level category was a bachelor's degree $(n=396,63.6 \%)$. Most of the respondents were married ( $n=543,87.2 \%$ ). In regards to the occupation, $64.0 \%$ were company employees. Lastly, the largest yearly income group was in the range of US\$27,771 to US\$ $37,001(n=151,24.2 \%)$, which was followed by US\$ 21,601 to US\$ $27,770(n=141,22.6 \%)$. Table 1 presents a detailed profile of the respondents.

Table 1. Profile of the respondents $(n=623)$.

\begin{tabular}{ccc}
\hline Variable & $n$ & Percentage \\
\hline Gender & & \\
Male & 266 & 42.7 \\
Female & 357 & 57.3 \\
Education Level & & \\
High school diploma & 132 & 21.0 \\
Associate's degree & 26 & 4.2 \\
Bachelor's degree & 396 & 63.6 \\
Graduate degree & 69 & 11.1 \\
Marital Status & & \\
Single & 79 & 12.7 \\
Occupation & 543 & 87.2 \\
Company employee & & 64.0 \\
Self-employed & 399 & 7.1 \\
Sales/service & 44 & 1.8 \\
Student & 11 & 1.4 \\
Civil servant & 9 & 7.9 \\
Professional & 49 & 16.5 \\
Other & 103 & 1.3 \\
Yearly income & 8 & 20.3 \\
Less than US\$ 16,600 & & 17.8 \\
US\$ 16,601 US\$ 21,600 & 126 & 22.6 \\
US\$ 21,601 US\$ 27,770 & 111 & 24.2 \\
US\$ 27,771 US 37,000 & 141 & 15.1 \\
More than US\$ 37,001 & 151 & \\
Mean Age = 32.85 years old & 94 & \\
\hline
\end{tabular}

Table 2 presents the profile of the respondents' travel characteristics. In regards to the total number of trips to Korea, the respondents indicated one time ( $n=127,20.4 \%)$, two times $(n=238,38.2 \%)$, three times $(n=146,23.4 \%)$, and more than four times $(n=112,17.9 \%)$. In addition, the main purpose of the trip was leisure $(n=548,88.0 \%)$. In regards to the length of stay in Korea, the respondents indicated one night $(n=6,1.0 \%)$, two nights $(n=61,9.8 \%)$, three nights $(n=197,31.6 \%)$, four nights $(n=190,30.5 \%)$, and more than five nights $(n=169,27.1 \%)$. The highest percentage category of the respondents reported they traveled with family or relatives $(n=328,52.6 \%)$, which was followed by friends $(n=216,34.7 \%)$. Lastly, the average expenditure for shopping was US $\$ 2800$. 
Table 2. Profile of the respondents' travel characteristics $(n=623)$.

\begin{tabular}{ccc}
\hline Variable & $N$ & Percentage \\
\hline Including this trip, how many times have & & \\
you visited Korea? & 127 & 20.4 \\
One time & 238 & 38.2 \\
Two times & 146 & 23.4 \\
Three times & 112 & 17.9 \\
More than four times & & \\
Leisure & 548 & 88.0 \\
Business & 28 & 4.5 \\
What is your main purpose for this trip? & 8 & 1.3 \\
Shopping & 39 & 6.3 \\
To meet friends or relatives & 6 & 1.0 \\
How long did you stay in Korea? & 61 & 9.8 \\
One night & 197 & 31.6 \\
Two nights & 190 & 30.5 \\
Three nights & 169 & 27.1 \\
Four nights & & \\
More than five nights & 45 & 7.2 \\
With whom did you travel? & 216 & 34.7 \\
Alone & 34 & 5.5 \\
Friend & 328 & 52.6 \\
Association or Company & Average & US\$ 2,800 \\
Family or Relatives & &
\end{tabular}

\section{Data analysis}

\subsection{Measurement Model}

The measurement model was assessed using confirmatory factor analysis (CFA) [112]. The specific items with their standardized factor loadings are presented in Table 3. The descriptive statistics and the associated measures, which include the average variance extracted (AVE), the composite reliabilities, the correlations, and the squared correlations [113-115] are reported in Table 4. The measurement model provided an acceptable fit [116] to the data (Table 4). For the individual measurement items, the factor loadings should be higher than 0.70 [117], demonstrating convergent validity. The values of the AVE for all of constructs were greater than the recommended value of $0.5[118,119]$, which also indicates that the convergent validity was well established. In addition, strong discriminant validity was confirmed, because the values of the square root of AVE for each construct were higher than the values of the squared correlation $\left(R^{2}\right)$ between a pair of constructs $[118,120]$. Lastly, the values of the composite reliability for all of the constructs were greater than the 0.70 threshold value [121], which suggests a high level of internal consistency [122].

\subsection{Structural Model}

Figure 2 and Table 5 display the results of the structural equation modeling (SEM) [123]. The proposed structural model had a satisfactory fit to the data $\left(\chi^{2}=286.773, \mathrm{NFI}=0.958, \mathrm{IFI}=0.979\right.$, $\mathrm{CFI}=0.979$, TLI $=0.974$, and RMSEA $=0.039$ ). The results of the SEM indicated that among the seven hypotheses, six hypotheses were statistically supported at the 0.05 level, having $t$ values greater than 1.96 [124]. 
Table 3. Confirmatory factor analysis: Items and loadings.

\begin{tabular}{cc}
\hline Construct and Scale Items & $\begin{array}{c}\text { Standardized } \\
\text { Loading }\end{array}$ \\
Country Image & \\
Cognitive Destination Image & 0.765 \\
I think that the image of Korea is affluent. & 0.772 \\
I think that the image of Korea is economically developed. & 0.794 \\
I think that the image of Korea is high living standards. & 0.847 \\
I think that the image of Korea is advanced science and technology. & 0.823 \\
Affective Destination Image & 0.852 \\
I think that the image of Korea is peace-loving. & 0.760 \\
I think that the image of Korea is friendly. & 0.797 \\
I think that the image of Korea is cooperative. & 0.884 \\
I think that the image of Korea is likable. & 0.852 \\
$\quad$ Tour Motivations & 0.821 \\
I expect to get mental relaxation from a visit to Korea. & \\
I hope to enjoy amusements from a visit to Korea. & 0.850 \\
Thour Quality & 0.819 \\
The tour to Korea provided experiences of beautiful scenery. & 0.822 \\
The tour to Korea was filled with historical and cultural legacy. & \\
I had many new experiences during the tour to Korea. & 0.779 \\
Tour Satisfaction & 0.825 \\
I was satisfied with my visit to Korea. & 0.838 \\
I enjoyed myself during my stay in Korea. & 0.842 \\
I was happy with my visit to Korea. & 0.838 \\
$\quad$ Word-of-Mouth & 0.855 \\
I said positive things about my visit to Korea. & \\
I recommended a visit to Korea. & \\
I encouraged others to visit Korea. & \\
\hline
\end{tabular}

a All factors loadings are significant at $p<0.001$.

Table 4. Descriptive statistics and associated measures.

\begin{tabular}{|c|c|c|c|c|c|c|c|c|c|}
\hline & $\begin{array}{l}\text { No. of } \\
\text { Items }\end{array}$ & $\begin{array}{l}\text { Mean } \\
\text { (S.D) }\end{array}$ & AVE & (1) & (2) & (3) & (4) & (5) & (6) \\
\hline (1) Cognitive Destination Image & 4 & $\begin{array}{c}4.29 \\
(0.88)\end{array}$ & 0.632 & $0.849^{\mathrm{a}}$ & $0.764^{\mathrm{b}}$ & 0.761 & 0.779 & 0.692 & 0.672 \\
\hline (2) Affective Destination Image & 4 & $\begin{array}{c}4.25 \\
(0.86)\end{array}$ & 0.630 & $0.584^{c}$ & 0.847 & 0.779 & 0.750 & 0.744 & 0.736 \\
\hline (3) Tour Motivations & 3 & $\begin{array}{c}4.12 \\
(0.82)\end{array}$ & 0.727 & 0.579 & 0.607 & 0.861 & 0.784 & 0.762 & 0.745 \\
\hline (4) Tour Quality & 3 & $\begin{array}{c}4.18 \\
(0.89)\end{array}$ & 0.690 & 0.607 & 0.563 & 0.615 & 0.874 & 0.753 & 0.747 \\
\hline (5) Tour Satisfaction & 3 & $\begin{array}{c}4.23 \\
(0.91)\end{array}$ & 0.663 & 0.479 & 0.554 & 0.581 & 0.567 & 0.848 & 0.787 \\
\hline (6) Word-of-Mouth & 3 & $\begin{array}{c}4.21 \\
(0.90)\end{array}$ & 0.714 & 0.452 & 0.542 & 0.555 & 0.558 & 0.619 & 0.834 \\
\hline
\end{tabular}

Goodness-of-fit statistics: $\chi^{2}=232.294, d f=140, \chi^{2} / d f=1.659, p<0.001, \mathrm{NFI}=0.966, \mathrm{IFI}=0.986, \mathrm{CFI}=0.986, \mathrm{TLI}=0.981$ and RMSEA $=0.033$

Note: $\mathrm{AVE}$ = average variance extracted; IFI = incremental fit index; $\mathrm{CFI}$ = comparative fit index; TLI = Tucker-Lewis index; RMSEA = root mean square error of approximation. ${ }^{\text {a }}$ composite reliabilities are along the diagonal;

${ }^{\mathrm{b}}$ correlations are above the diagonal; ${ }^{\mathrm{c}}$ squared correlations are below the diagonal. 


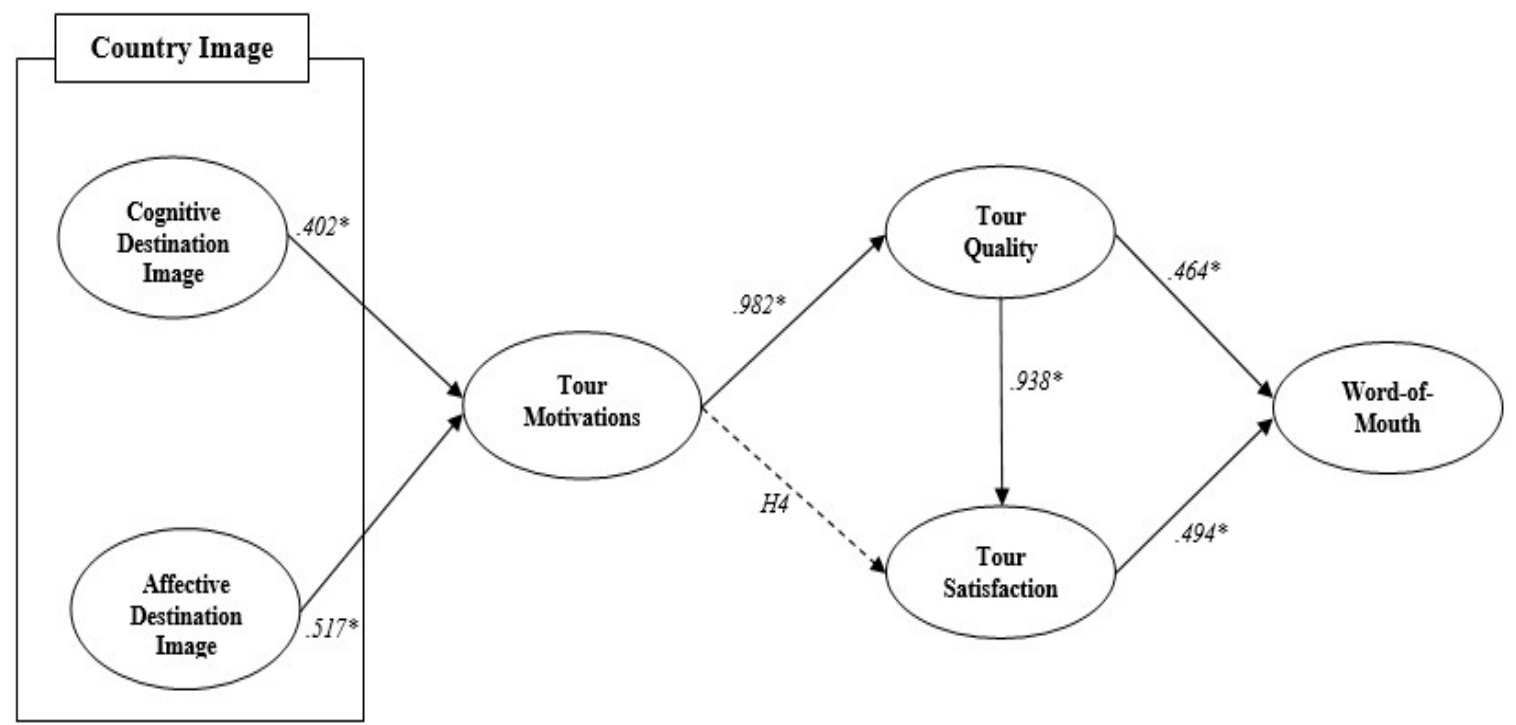

Note: ${ }^{*} p<.05$

Figure 2. Standardized theoretical path coefficients.

Table 5. Standardized parameter estimates for the structural model.

\begin{tabular}{|c|c|c|c|c|c|}
\hline Independent Variable & & $\begin{array}{c}\text { Dependent } \\
\text { Variable }\end{array}$ & $\begin{array}{l}\text { Standardized } \\
\text { Estimate }\end{array}$ & $t$-Value & Hypothesis \\
\hline H1 Cognitive Destination Image & $\rightarrow$ & Tour Motivations & 0.402 & 6.003 & Supported \\
\hline H2 Affective Destination Image & $\rightarrow$ & Tour Motivations & 0.517 & 6.686 & Supported \\
\hline H3 Tour Motivations & $\rightarrow$ & Tour Quality & 0.982 & 16.706 & Supported \\
\hline H4 Tour Motivations & $\rightarrow$ & Tour Satisfaction & 0.125 & 0.231 & Not supported \\
\hline H5 Tour Quality & $\rightarrow$ & Tour Satisfaction & 0.938 & 16.022 & Supported \\
\hline H6 Tour Quality & $\rightarrow$ & Word-of-Mouth & 0.464 & 2.754 & Supported \\
\hline H7 Tour Satisfaction & $\rightarrow$ & Word-of-Mouth & 0.494 & 2.972 & Supported \\
\hline \multicolumn{6}{|c|}{$\begin{aligned} \text { Goodness-of-fit statistics: } \chi^{2}=286.773, d f= & 149, \chi^{2} / d f=1.925, p<0.001, \mathrm{NFI}=0.958, \mathrm{IFI}=0.979, \mathrm{CFI}=0.979, \mathrm{TLI}= \\
& 0.974, \text { and RMSEA }=0.039\end{aligned}$} \\
\hline
\end{tabular}

Note: $\mathrm{AVE}=$ average variance extracted; $\mathrm{IFI}=$ incremental fit index; $\mathrm{CFI}=$ comparative fit index; $\mathrm{TLI}=$ Tucker-Lewis index; RMSEA = root mean square error of approximation.

\section{Discussion and Implications}

China is known as the largest potential tourism market for the Korean tourism industry. The rapid increase of Chinese outbound tourism is well known, and it has become the prime focus of scholars [125]. The tourism facts and figures show that by 2020 the number of tourists travelling from China will exceed 100 million [126]. In November 2019, 505,369 Chinese tourists entered Korea, while in 2018, 404,256 Chinese tourists visited Korea. This represents a 25.01\% total increase in Chinese tourists travelling to Korea [127]. Regardless of the massive tourism potential of Chinese outbound travelers, a few studies have focused on the experiences of the Chinese tourists traveling to Korea [72,128,129]. In this regard, the present study assessed the motivations of assessed Chinese tourists who visit Korea in the context of the assessed country's image. To gain a competitive advantage, it is much more important for both the Korean government and the tourism industry to develop and understand the different procedures in order to uncover the destination choices the Chinese travelers prefer. In this regard, the present study analyzed the causal association among the two types of the country's image, which include the cognitive and the affective, the tour motivation, the tour quality, the tour satisfaction, and the word-of-mouth of the Chinese travelers in Korea.

First, this is the only study that has attempted to explore the country's image while focusing on the Chinese tourists who visit Korea to determine their tour motivation. Prior research analyzed the Chinese travelers in Korea in different contexts, such as medical tourism and K-culture [130,131]. 
However, the tour motivation has not been thoroughly examined previously, which is the prime purpose of the study regarding the Chinese tourists in Korea. In this regard, this study is essential, because it delivered how the Chinese tourists' motivational level can be increased by providing a better destination image, and this will ultimately lead to good tour quality and satisfaction. This will further help in spreading positive WOM. Furthermore, this study provides the significances in inducing the tourists' intentions towards Korea as a tourism destination through the sub-dimensions of a country's image, which include the cognitive destination image and the affective destination image, which have not been previously examined. Therefore, the current research extended the literature of a country's image by evincing the impact of these dimensions in the Korean tourism industry and provided a complete understanding of the Chinese tourists' motivation to travel to Korea.

Second, the findings of our study revealed that both the cognitive image and the affective image have significant effects on the tour motivation. The results revealed that the path from the cognitive image to the tour motivation $(\beta=0.402$ and $p<0.05)$ and the affective image to the tour motivation $(\beta=0.517$ and $p<0.05)$ were significant. These results recommend that during the promotion of a tour destination, the Korean tourism organizations should focus on both the physical and the tangible aspects as well as concentrate on the intangible and the affective attributes, which include the tourists' emotions and experiences when they visit a specific destination. The cognitive aspect of destination image deals with the perception of tourist destination attributes, which can be functional/tangible (e.g., accommodation and cultural attractions) and psychological/abstract (e.g., friendly atmosphere). On the other hand, the affective aspect denotes the emotion evoked by a tourist destination (e.g., pleasure and excitement). The finding suggests that a destination image is established by a process including the two distinct components of the image. The formation process indicates that an individual's beliefs about a destination (i.e., cognitive image) induce his/her feeling of a destination (i.e., affective image). This would help make the destination different and attractive in the eyes of the tourists. The tourists' motivations examined in this research should be more considerable while promoting a specific destination. Additionally, the target market should also be divided accordingly, because it is the most important aspect of the section of a destination.

Third, this study investigated how the tourism motivation affects the quality of the tour experience. From the findings of Hypothesis 3, the $\beta$ value of the path from the tour motivation to the tour quality is 0.982 , and it has a p-value that is less than 0.05 , which proves that the tour motivations affect the tour quality, so the hypothesis is accepted. Our findings are consistent with the results from Lee, Jeon and Kim [72]. They revealed that the higher the tour motivations, the higher the quality of the tour experience will be. Moreover, a positive association is also presented between a country's image and the tour motivation. Therefore, when tourists' expectations regarding a country's image are higher, Korean tourist organizations should pay more attention to improving the travelers' motivation, and they should provide the best quality and more competitive travel products in order to meet the high expectations of the Chinese visitors. This should be a priority in order to increase the importance of tourism by promoting cultural events. The famous tourism brands inside and outside also have a positive impact on the Chinese tourists, so they also need to motivate them to visit Korea.

Fourth, from the findings of this research, the tour motivation has an insignificant effect on tourist satisfaction $(\beta=0.125$ and $p>0.05)$. This finding is consistent with the finding from Yoon and Uysal [87]. Some of the previous studies empirically demonstrated that this relation is significant in several contexts [88-90,132]. Previously, no empirical research has conducted a pivotal association between the tour motivation and satisfaction for the Chinese tourists who visited in Korea. Hence, it would be interesting to examine whether the above pivotal association is present in the studied model that is applied to Korean tourism. Our findings further suggest that in order to improve tour satisfaction, destination managers must consider different types of tour motivations, including pull and push motivations, which are related to external sources such as destination attributes and internal sources such as the revisit intention of the tourists. It will help to provide appropriate destination attractions and activities, which should be allocated and delivered to tourists in order to enhance destination 
competitiveness. This indicates that tourists' motivation affects their destination loyalty, which includes revisiting destinations and recommending them to others. Thus, destination managers should focus more on tourists' emotional feelings to increase motivation. Finally, it can be intuitively assumed that if tourists are satisfied with their tour quality, they are more satisfied and are willing to revisit destinations and recommend them to other people.

Fifth, from the findings of Hypothesis 5 , the $\beta$ value of the path from the tour motivation to the tour quality is 0.938 , and it has a $p$-value that is less than 0.05 , which proves that the tour quality positively and significantly affects the tour satisfaction. Our findings are consistent with the results from Lee, Jeon and Kim [72] and Gim [83]. They suggested that the tour satisfaction will be higher if the tour quality that is experienced by the tourists is high. Based on the findings of the present study, it is suggested that the Korean tourism organizations should establish specialized shops that sell souvenirs and handicrafts, and they should develop hot springs for health, leisure, and relaxation. These may be included in cultural and arts festivals for entertainment and would keep the Chinese travelers adequately stimulated. Moreover, it is essential to develop strong cooperation among all levels of government and tourism organizations in order to understand the interests and the priorities of the Chinese tourists. Consistently, proper educational training and language services for the Chinese travelers need to be extended. This will ultimately help to implement an efficient policy to improve the tourism industry and strengthen the competitive advantage both in terms of quality and quantity, which would encourage the Chinese travelers to select Korea as a primary destination and visit.

Sixth, both the tour quality $(\beta=0.464$ and $p<0.05)$ and the tour satisfaction $(\beta=0.494$ and $p<0.05)$ were found to be predictors of the word of mouth, which is in line the results from Hwang and Lee [110]. They suggested that the tour satisfaction improves the word of mouth. They also confirmed that when tourists are highly satisfied with the tour quality, they are more likely to recommend the destination to others. Likewise, the findings of the present research are similar to the theory's implications, which illustrate that the tour motivation has a positive influence on the tour quality, and this leads to the customers' satisfaction. Additionally, this will encourage the tourists to positively describe the destination to others. For example, when the Chinese tourists have a positive experience with the Korean tourist areas, they are more likely to be motivated to travel there. If they perceive that a tour has good service quality, they feel more satisfied and will recommend the travel destinations to others.

Due to the growing number of Chinese outbound tourists and lavish expenditure during their trip, a better understanding of Chinese tourists' destination choices is critical for the Korean Government, the Korea Tourism Organization and tourism operators. Based on the results of our study, it is concluded that Korean destination managers must improve both the cognitive and affective aspects of Korea's image. For example, the Korean tourism industry should establish a more friendly tourism environment for Chinese tourists, including direction signs in Chinese and Chinese docents at historical sites. In that way, Chinese tourists might feel more comfortable and pleased during their trip to Korea, would be more satisfied with the quality and indeed enhance their future travel behaviors, such as repeating visitor WOM. Similarly, the Korean tourism industry must understand and satisfy the demands of Chinese tourists. For example, establishing regular satisfaction surveys at the airport or popular tourist sites can be conducted for Chinese tourists. Once they are satisfied, they are more likely to revisit or advocate Korea as a tourist destination. Tourism marketers should develop various actions to promote the strengths of the tourist destination. Hence, communication through mass media such as TV dramas or movies may be included in these actions. Filming TV dramas or movies at popular tourist sites can be a natural way to promote the tourist destination and build its favorable image.

\section{Limitations and Future Research}

This study provides important theoretical and practical implications, which are mentioned above, but has the following limitations. First, this paper focused only on the Chinese tourists who visited South Korea, so it is difficult to apply the findings of the paper to tourists of different nationalities. Second, this paper employed an online survey in order to collect data, which could lead to a negative 
influence, such as selection biases [133]. Hence, future research needs to use different types of data collection methods to reduce the biases.

Author Contributions: Conceptualization: J.H.; methodology: J.H.; formal analysis: J.H.; investigation: K.-W.L. and M.A.; resources: J.H.; data Curation: H.K.; writing-original draft preparation: J.H., K.-W.L. and M.A.; writing-review and editing: J.H., K.-W.L., and M.A.; supervision: J.H. All authors have read and agreed to the published version of the manuscript.

Funding: The study received no external funding.

Acknowledgments: This manuscript was supported by Daegu University Research Grants in 2018.

Conflicts of Interest: The authors declare no conflict of interest.

\section{References}

1. United Nations World Tourism Organization (UNWTO). China-The New Number One Tourism Source Market in the World; Press Release 4 April 2013; UNWTO: Madrid, Spain, 2013.

2. China National Tourism Administration. The Yearbook of China Tourism Statistics; China National Tourism Administration: Beijimg, China, 2016.

3. Hanqin, Q.Z.; Hailin, Q. The trends of China's outbound travel to Hong Kong and their implications. J. Vacat. Mark. 1996, 2, 373-381. [CrossRef]

4. Kandampully, J. The impact of demand fluctuation on the quality of service: A tourism industry example. Manag. Serv. Qual. Int. J. 2000, 10, 10-19. [CrossRef]

5. Bojanic, D.C. The use of advertising in managing destination image. Tour. Manag. 1991, 12, 352-355. [CrossRef]

6. Eagles, P.F. The travel motivations of Canadian ecotourists. J. Travel Res. 1992, 31, 3-7. [CrossRef]

7. Fodness, D. Measuring tourist motivation. Ann. Tour. Res. 1994, 21, 555-581. [CrossRef]

8. Crompton, J.L. Motivations for pleasure vacation. Ann. Tour. Res. 1979, 6, 408-424. [CrossRef]

9. Kozak, M. Comparative analysis of tourist motivations by nationality and destinations. Tour. Manag. 2002, 23, 221-232. [CrossRef]

10. Marine-Roig, E. Destination image analytics through traveller-generated content. Sustainability 2019, 11, 3392. [CrossRef]

11. Dann, G.M. Content/semiotic analysis: Applications for tourism research. Tour. Dev. Issues Vulnerable Ind. 2005, 20, 27-43.

12. Gartner, W. Image Formation Process. In Communication and Channel Systems in Tourism Marketing; Uysal, M., Fesenmaier, D., Eds.; Haworth Press: New York, NY, USA, 1993.

13. Khairani, K.; Setyowardhani, H. Analysis on Variables Affecting the Creation of Tourist Destination Image: Case Study on Domestic Tourists Visiting Yogyakarta between 2007 to 2009. Asean Mark. J. 2013, 2, 43-54. [CrossRef]

14. Beerli, A.; Martin, J.D. Factors influencing destination image. Ann. Tour. Res. 2004, 31, 657-681. [CrossRef]

15. Kanwel, S.; Lingqiang, Z.; Asif, M.; Hwang, J.; Hussain, A.; Jameel, A. The Influence of Destination Image on Tourist Loyalty and Intention to Visit: Testing a Multiple Mediation Approach. Sustainability 2019, 11, 6401. [CrossRef]

16. San Martín, H.; Del Bosque, I.A.R. Exploring the cognitive-affective nature of destination image and the role of psychological factors in its formation. Tour. Manag. 2008, 29, 263-277. [CrossRef]

17. Kozak, M.; Rimmington, M. Tourist satisfaction with Mallorca, Spain, as an off-season holiday destination. J. Travel Res. 2000, 38, 260-269. [CrossRef]

18. Lee, C.-K.; Lee, Y.-K.; Lee, B. Korea's destination image formed by the 2002 World Cup. Ann. Tour. Res. 2005, 32, 839-858. [CrossRef]

19. Lee, C.-K.; Yoon, Y.-S.; Lee, S.-K. Investigating the relationships among perceived value, satisfaction, and recommendations: The case of the Korean DMZ. Tour. Manag. 2007, 28, 204-214. [CrossRef]

20. Zhang, H.; Fu, X.; Cai, L.A.; Lu, L. Destination image and tourist loyalty: A meta-analysis. Tour. Manag. 2014, 40, 213-223. [CrossRef]

21. Baloglu, S.; McCleary, K.W. A model of destination image formation. Ann. Tour. Res. 1999, 26, 868-897. [CrossRef] 
22. Qu, H.; Kim, L.H.; Im, H.H. A model of destination branding: Integrating the concepts of the branding and destination image. Tour. Manag. 2011, 32, 465-476. [CrossRef]

23. Hosany, S.; Ekinci, Y.; Uysal, M. Destination image and destination personality. Int. J. Cult. Tour. Hosp. Res. 2007, 1, 62-81. [CrossRef]

24. MacKay, K.J.; Fesenmaier, D.R. An exploration of cross-cultural destination image assessment. J. Travel Res. 2000, 38, 417-423. [CrossRef]

25. Baloglu, S.; Mangaloglu, M. Tourism destination images of Turkey, Egypt, Greece, and Italy as perceived by US-based tour operators and travel agents. Tour. Manag. 2001, 22, 1-9. [CrossRef]

26. Russell, J.A.; Snodgrass, J. Emotion and the environment. In Handbook of Environmental Psychology; CRC Press: Boca Raton, FL, USA, 1987; Volume 1, pp. 245-281.

27. Russell, J.A. A circumplex model of affect. J. Personal. Soc. Psychol. 1980, 39, 1161. [CrossRef]

28. Chen, C.-F.; Tsai, D. How destination image and evaluative factors affect behavioral intentions? Tour. Manag. 2007, 28, 1115-1122. [CrossRef]

29. Uysal, M.; Jurowski, C. Testing the push and pull factors. Ann. Tour. Res. 1994, 21, 844-846. [CrossRef]

30. Weaver, P.A.; McCleary, K.W.; Lapisto, L.; Damonte, L.T. The relationship of destination selection attributes to psychological, behavioral and demographic variables. J. Hosp. Leis. Mark. 1994, 2, 93-109. [CrossRef]

31. Iso-Ahola, S.E. Toward a social psychological theory of tourism motivation: A rejoinder. Ann. Tour. Res. 1982, 9, 256-262. [CrossRef]

32. McCartney, G.; Butler, R.; Bennett, M. A strategic use of the communication mix in the destination image-formation process. J. Travel Res. 2008, 47, 183-196. [CrossRef]

33. Law, R.; Cheung, C.; Lo, A. The relevance of profiling travel activities for improving destination marketing strategies. Int. J. Contemp. Hosp. Manag. 2004, 16, 355-362. [CrossRef]

34. Gnoth, J. Tourism motivation and expectation formation. Ann. Tour. Res. 1997, 24, 283-304. [CrossRef]

35. Chon, K.S. Understanding recreational traveler's motivation, attitude and satisfaction. Tour. Rev. 1989, 44, 3-7. [CrossRef]

36. Ap, J.; Mok, C. Motivations and barriers to vacation travel in Hong Kong. In Proceedings of the Asia Pacific tourism association 1996 conference-quality research, quality tourism, Townsville, Australia, 1996.

37. Jang, S.C.; Morrison, A.M.; O'Leary, J.T. Benefit segmentation of Japanese pleasure travelers to the USA and Canada: Selecting target markets based on the profitability and risk of individual market segments. Tour. Manag. 2002, 23, 367-378. [CrossRef]

38. Beerli, A.; Martín, J.D. Tourists' characteristics and the perceived image of tourist destinations: A quantitative analysis-A case study of Lanzarote, Spain. Tour. Manag. 2004, 25, 623-636. [CrossRef]

39. Moon, H.; Han, H. Tourist experience quality and loyalty to an island destination: The moderating impact of destination image. J. Travel Tour. Mark. 2019, 36, 43-59. [CrossRef]

40. Um, S.; Crompton, J.L. Attitude determinants in tourism destination choice. Ann. Tour. Res. 1990, 17, 432-448. [CrossRef]

41. Moutinho, L. Consumer behaviour in tourism. Eur. J. Mark. 1987, 21, 5-44. [CrossRef]

42. Pearce, P.L. Defining tourism study as a specialism: A justification and implications. Teoros Int. 1993, 1, $25-32$.

43. Han, H.; Lee, K.-S.; Chua, B.-L.; Lee, S.; Kim, W. Role of airline food quality, price reasonableness, image, satisfaction, and attachment in building re-flying intention. Int. J. Hosp. Manag. 2019, 80, 91-100. [CrossRef]

44. Lawson, F.; Baud-Bovy, M. Tourism and Recreation Development, a Handbook of Physical Planning; Architectural Press: New York, NY, USA, 1977.

45. Song, H.; Wang, J.; Han, H. Effect of image, satisfaction, trust, love, and respect on loyalty formation for name-brand coffee shops. Int. J. Hosp. Manag. 2019, 79, 50-59. [CrossRef]

46. Han, H.; Nguyen, H.N.; Song, H.; Lee, S.; Chua, B.-L. Impact of functional/cognitive and emotional advertisements on image and repurchase intention. J. Hosp. Mark. Manag. 2019, 28, 446-471. [CrossRef]

47. Kotler, P.; Haider, D.H.; Rein, I.J. Marketing Places: Attracting Investment, Industry, and Tourism to Cities, States, and Nations; Free Press: New York, NY, USA, 1993.

48. Castro, C.B.; Armario, E.M.; Ruiz, D.M. The influence of market heterogeneity on the relationship between a destination's image and tourists' future behaviour. Tour. Manag. 2007, 28, 175-187. [CrossRef]

49. Kim, S.; Yoon, Y. The hierarchical effects of affective and cognitive components on tourism destination image. J. Travel Tour. Mark. 2003, 14, 1-22. [CrossRef] 
50. Son, A.; Pearce, P. Multi-faceted image assessment: International students' views of Australia as a tourist destination. J. Travel Tour. Mark. 2005, 18, 21-35. [CrossRef]

51. Wang, C.L.; Li, D.; Barnes, B.R.; Ahn, J. Country image, product image and consumer purchase intention: Evidence from an emerging economy. Int. Bus. Rev. 2012, 21, 1041-1051. [CrossRef]

52. Martin, I.M.; Eroglu, S. Measuring a multi-dimensional construct: Country image. J. Bus. Res. 1993, 28, 191-210. [CrossRef]

53. Desborde, R.D. Development and Testing of a Psychometric Scale to Measure Country-Of-Origin Image; The Florida State University: Tallahassee, FL, USA, 1991.

54. Kim, S.; Kim, S.; Han, H. Effects of TV drama celebrities on national image and behavioral intention. Asia Pac. J. Tour. Res. 2019, 24, 233-249. [CrossRef]

55. Echtner, C.M.; Ritchie, J.B. The meaning and measurement of destination image. J. Tour. Stud. 1991, 2, 2-12.

56. Han, H.; Olya, H.G.; Untaru, E.N.; Ispas, A.; Kim, J.J.; Kim, W. Impact of airport green atmospherics on mental health value, image, and loyalty among visitors and workers. Bus. Strategy Environ. 2020, 29, 1186-1198. [CrossRef]

57. Walmsley, D.; Jenkins, J.M. Appraisive images of tourist areas: Application of personal constructs. Aust. Geogr. 1993, 24, 1-13. [CrossRef]

58. Laroche, M.; Papadopoulos, N.; Heslop, L.A.; Mourali, M. The influence of country image structure on consumer evaluations of foreign products. Int. Mark. Rev. 2005, 22, 96-115. [CrossRef]

59. Papadopoulos, N.G.; Heslop, L.A. Country Equity and Product-Country Images: State-Of-The-Art in Research and Implications; Edward Elgar: Cheltenham, UK, 2003.

60. Roth, K.P.; Diamantopoulos, A. Advancing the country image construct. J. Bus. Res. 2009, 62, 726-740. [CrossRef]

61. Baloglu, S.; Brinberg, D. Affective images of tourism destinations. J. Travel Res. 1997, 35, 11-15. [CrossRef]

62. Alvarez, M.D.; Campo, S. The influence of political conflicts on country image and intention to visit: A study of Israel's image. Tour. Manag. 2014, 40, 70-78. [CrossRef]

63. Wood, W. Retrieval of attitude-relevant information from memory: Effects on susceptibility to persuasion and on intrinsic motivation. J. Personal. Soc. Psychol. 1982, 42, 798. [CrossRef]

64. Han, H.; Hyun, S.S. Impact of hotel-restaurant image and quality of physical-environment, service, and food on satisfaction and intention. Int. J. Hosp. Manag. 2017, 63, 82-92. [CrossRef]

65. Ittelson, W. Environmental Perception and Contemporary Perceptual Theory; Seminar: New York, NY, USA, 1973; pp. 11-30.

66. Cai, L.A. Cooperative branding for rural destinations. Ann. Tour. Res. 2002, 29, 720-742. [CrossRef]

67. Stern, E.; Krakover, S. The formation of a composite urban image. Geogr. Anal. 1993, 25, 130-146. [CrossRef]

68. Baloglu, S.; Love, C. Association meeting planners' perceptions and intentions for five major US convention cities: The structured and unstructured images. Tour. Manag. 2005, 26, 743-752. [CrossRef]

69. Parasuraman, A.; Zeithaml, V.A.; Berry, L.L. A conceptual model of service quality and its implications for future research. J. Mark. 1985, 49, 41-50. [CrossRef]

70. Zeithaml, V.A. Defining and Relating Price, Perceived Quality, and Perceived Value; Marketing Science Institute: Cambridge, MA, USA, 1987.

71. Hsu, C.H.; Kang, S.K.; Lam, T. Reference group influences among Chinese travelers. J. Travel Res. 2006, 44, 474-484. [CrossRef]

72. Lee, S.; Jeon, S.; Kim, D. The impact of tour quality and tourist satisfaction on tourist loyalty: The case of Chinese tourists in Korea. Tour. Manag. 2011, 32, 1115-1124. [CrossRef]

73. Kim, S.S.; Guo, Y.; Agrusa, J. Preference and positioning analyses of overseas destinations by mainland Chinese outbound pleasure tourists. J. Travel Res. 2005, 44, 212-220. [CrossRef]

74. Baker, D.A.; Crompton, J.L. Quality, satisfaction and behavioral intentions. Ann. Tour. Res. 2000, $27,785-804$. [CrossRef]

75. Spreng, R.A.; MacKenzie, S.B.; Olshavsky, R.W. A reexamination of the determinants of consumer satisfaction. J. Mark. 1996, 60, 15-32. [CrossRef]

76. Parasuraman, A.; Zeithaml, V.A.; Berry, L.L. Servqual: A multiple-item scale for measuring consumer perc. J. Retail. 1988, 64, 12-40.

77. Kane, M.J.; Zink, R. Package adventure tours: Markers in serious leisure careers. Leis. Stud. 2004, 23, 329-345. [CrossRef] 
78. Lee, Y.; Dattilo, J.; Howard, D. The complex and dynamic nature of leisure experience. J. Leis. Res. 1994, 26, 195-211. [CrossRef]

79. Mannell, R.C.; Iso-Ahola, S.E. Psychological nature of leisure and tourism experience. Ann. Tour. Res. 1987, 14, 314-331. [CrossRef]

80. Cronin, J.J., Jr.; Taylor, S.A. Measuring service quality: A reexamination and extension. J. Mark. 1992, 56, 55-68. [CrossRef]

81. Beard, J.G.; Ragheb, M.G. Measuring leisure satisfaction. J. Leis. Res. 1980, 12, 20-33. [CrossRef]

82. Tribe, J.; Snaith, T. From SERVQUAL to HOLSAT: Holiday satisfaction in Varadero, Cuba. Tour. Manag. 1998, 19, 25-34. [CrossRef]

83. Gim, T.-H.T. Tourist satisfaction, image, and loyalty from an interregional perspective: An analysis of neighboring areas with distinct characteristics. Sustainability 2018, 10, 1283. [CrossRef]

84. Tian-Cole, S.; Cromption, J. A conceptualization of the relationships between service quality and visitor satisfaction, and their links to destination selection. Leis. Stud. 2003, 22, 65-80. [CrossRef]

85. Bigne, J.E.; Sanchez, M.I.; Sanchez, J. Tourism image, evaluation variables and after purchase behaviour: Inter-relationship. Tour. Manag. 2001, 22, 607-616. [CrossRef]

86. Cole, S.T.; Scott, D. Examining the mediating role of experience quality in a model of tourist experiences. J. Travel Tour. Mark. 2004, 16, 79-90. [CrossRef]

87. Yoon, Y.; Uysal, M. An examination of the effects of motivation and satisfaction on destination loyalty: A structural model. Tour. Manag. 2005, 26, 45-56. [CrossRef]

88. Ross, E.L.D.; Iso-Ahola, S.E. Sightseeing tourists' motivation and satisfaction. Ann. Tour. Res. 1991, 18, 226-237. [CrossRef]

89. Lee, C.-K.; Lee, Y.-K.; Wicks, B.E. Segmentation of festival motivation by nationality and satisfaction. Tour. Manag. 2004, 25, 61-70. [CrossRef]

90. Lin, J. An integrated analysis of motivation and satisfaction of different tourist types on willingness to revisit, An example of the farm resorts. J. Outdoor Recreat. Study 2005, 18, 25-47.

91. Kim, H.; Kim, J.J.; Asif, M. The Antecedents and Consequences of Travelers' Well-Being Perceptions: Focusing on Chinese Tourist Shopping at a Duty Free. Int. J. Environ. Res. Public Health 2019, 16, 5081. [CrossRef]

92. Hwang, J.; Kim, J.J.; Lee, J.S.-H.; Sahito, N. How to Form Wellbeing Perception and Its Outcomes in the Context of Elderly Tourism: Moderating Role of Tour Guide Services. Int. J. Environ. Res. Public Health 2020, 17, 1029. [CrossRef]

93. Harrison-Walker, L.J. The measurement of word-of-mouth communication and an investigation of service quality and customer commitment as potential antecedents. J. Serv. Res. 2001, 4, 60-75. [CrossRef]

94. Hwang, J.; Lyu, S.O. Understanding first-class passengers' luxury value perceptions in the US airline industry. Tour. Manag. Perspect. 2018, 28, 29-40. [CrossRef]

95. Koo, B.; Yu, J.; Han, H. The role of loyalty programs in boosting hotel guest loyalty: Impact of switching barriers. Int. J. Hosp. Manag. 2020, 84, 1-10. [CrossRef]

96. Söderlund, M. Customer satisfaction and its consequences on customer behaviour revisited. Int. J. Serv. Ind. Manag. 1998, 9, 169-188. [CrossRef]

97. Mehran, J.; Olya, H.G.; Han, H.; Kapuscinski, G. Determinants of canal boat tour participant behaviours: An explanatory mixed-method approach. J. Travel Tour. Mark. 2020, 37, 112-127. [CrossRef]

98. Manzoor, F.; Wei, L.; Asif, M.; Haq, M.Z.u.; Rehman, H.u. The Contribution of Sustainable Tourism to Economic Growth and Employment in Pakistan. Int. J. Environ. Res. Public Health 2019, 16, 3785. [CrossRef]

99. Heung, V.C.; Wong, M.; Qu, H. Airport-restaurant service quality in Hong Kong: An application of SERVQUAL. Cornell Hotel Restaur. Adm. Q. 2000, 41, 86-96. [CrossRef]

100. Oliver, R.L. A cognitive model of the antecedents and consequences of satisfaction decisions. J. Mark. Res. 1980, 17, 460-469. [CrossRef]

101. Jones, T.O.; Sasser, W.E. Why satisfied customers defect. Harv. Bus. Rev. 1995, 73, 88-99. [CrossRef]

102. Day, R.L.; Landon, E.L. Toward a theory of consumer complaining behavior. Consum. Ind. Buy. Behav. 1977, 95, 425-437.

103. Cronin, J.J., Jr.; Brady, M.K.; Hult, G.T.M. Assessing the effects of quality, value, and customer satisfaction on consumer behavioral intentions in service environments. J. Retail. 2000, 76, 193-218. [CrossRef] 
104. Han, H.; Jongsik, Y.; Hyun, S.S. Nature based solutions and customer retention strategy: Eliciting customer well-being experiences and self-rated mental health. Int. J. Hosp. Manag. 2020, 86, 1-10. [CrossRef]

105. Hwang, J.; Hyun, S.S. First-class airline travelers' tendency to seek uniqueness: How does it influence their purchase of expensive tickets? J. Travel Tour. Mark. 2017, 34, 935-947. [CrossRef]

106. Petrick, J.F. Are loyal visitors desired visitors? Tour. Manag. 2004, 25, 463-470. [CrossRef]

107. Li, D.; Wang, C.L.; Jiang, Y.; Barnes, B.R.; Zhang, H. The asymmetric influence of cognitive and affective country image on rational and experiential purchases. Eur. J. Mark. 2014, 48, 2153-2175. [CrossRef]

108. Tang, Y. Travel motivation, destination image and visitor satisfaction of international tourists after the 2008 Wenchuan earthquake: A structural modelling approach. Asia Pac. J. Tour. Res. 2014, 19, 1260-1277. [CrossRef]

109. Hwang, J.; Lee, J.J. Understanding customer-customer rapport in a senior group package context. Int. J. Contemp. Hosp. Manag. 2019, 31, 2187-2204. [CrossRef]

110. Hwang, J.; Lee, J. Relationships among senior tourists' perceptions of tour guides' professional competencies, rapport, satisfaction with the guide service, tour satisfaction, and word of mouth. J. Travel Res. 2019, 58, 1331-1346. [CrossRef]

111. Hennig-Thurau, T.; Gwinner, K.P.; Gremler, D.D. Understanding relationship marketing outcomes: An integration of relational benefits and relationship quality. J. Serv. Res. 2002, 4, 230-247. [CrossRef]

112. Han, H.; Sahito, N.; Thi Nguyen, T.V.; Hwang, J.; Asif, M. Exploring the Features of Sustainable Urban Form and the Factors that Provoke Shoppers towards Shopping Malls. Sustainability 2019, 11, 4798. [CrossRef]

113. Asif, M.; Qing, M.; Hwang, J.; Shi, H. Ethical Leadership, Affective Commitment, Work Engagement, and Creativity: Testing a Multiple Mediation Approach. Sustainability 2019, 11, 4489. [CrossRef]

114. Hussain, A.; Asif, M.; Jameel, A.; Hwang, J. Measuring OPD Patient Satisfaction with Different Service Delivery Aspects at Public Hospitals in Pakistan. Int. J. Environ. Res. Public Health 2019, 16, 2340. [CrossRef]

115. Hussain, A.; Asif, M.; Jameel, A.; Hwang, J.; Sahito, N.; Kanwel, S. Promoting OPD Patient Satisfaction through Different Healthcare Determinants: A Study of Public Sector Hospitals. Int. J. Environ. Res. Public Health 2019, 16, 3719. [CrossRef] [PubMed]

116. Qing, M.; Asif, M.; Hussain, A.; Jameel, A. Exploring the impact of ethical leadership on job satisfaction and organizational commitment in public sector organizations: The mediating role of psychological empowerment. Rev. Manag. Sci. 2019, 1-28. [CrossRef]

117. Asif, M.; Jameel, A.; Sahito, N.; Hwang, J.; Hussain, A.; Manzoor, F. Can Leadership Enhance Patient Satisfaction? Assessing the Role of Administrative and Medical Quality. Int. J. Environ. Res. Public Health 2019, 16, 3212. [CrossRef] [PubMed]

118. Fornell, C.; Larcker, D.F. Evaluating Structural Equation Models with Unobservable Variables and Measurement Error. J. Mark. Res. 1981, 18, 39-50. [CrossRef]

119. Asif, M.; Jameel, A.; Hussain, A.; Hwang, J.; Sahito, N. Linking Transformational Leadership with Nurse-Assessed Adverse Patient Outcomes and the Quality of Care: Assessing the Role of Job Satisfaction and Structural Empowerment. Int. J. Environ. Res. Public Health 2019, 16, 2381. [CrossRef]

120. Jameel, A.; Asif, M.; Hussain, A.; Hwang, J.; Sahito, N.; Bukhari, M.H. Assessing the Moderating Effect of Corruption on the E-Government and Trust Relationship: An Evidence of an Emerging Economy. Sustainability 2019, 11, 6540. [CrossRef]

121. Hair, J.F.; Black, W.C.; Anderson, R.E.; Babin, B.J. Multivariate Data Analysis; Cengage Learning EMEA: Boston, MA, USA, 2018.

122. Manzoor, F.; Wei, L.; Hussain, A.; Asif, M.; Shah, S.I.A. Patient Satisfaction with Health Care Services; An Application of Physician's Behavior as a Moderator. Int. J. Environ. Res. Public Health 2019, 16, 3318. [CrossRef]

123. Jameel, A.; Asif, M.; Hussain, A. Good Governance and Public Trust: Assessing the Mediating Effect of E-Government in Pakistan. Lex Localis J. Local Self Gov. 2019, 17, 299-320. [CrossRef]

124. Jameel, A.; Asif, M.; Hussain, A.; Hwang, J.; Bukhari, M.H.; Mubeen, S.; Kim, I. Improving Patient behavioral Consent through Different Service Quality Dimensions: Assessing the Mediating Role of Patient Satisfaction. Int. J. Environ. Res. Public Health 2019, 16, 4736. [CrossRef] [PubMed]

125. Cai, L.A.; Li, M.; Knutson, B.J. Research on China outbound market: A meta-review. J. Hosp. Leis. Mark. 2008, 16, 5-20. [CrossRef] 
126. World Tourism Organization. Chinese Outbound Tourism Madrid; World Tourism Organization: Madrid, Spain, 2003.

127. Korea Tourism Organization. Tourism statistics; Korea Tourism Organization: Seoul, Korea, 2019.

128. Kim, M.-S.; Thapa, B.; Kim, H. International Tourists' Perceived Sustainability of Jeju Island, South Korea. Sustainability 2018, 10, 73. [CrossRef]

129. Zhang, H.; Cho, T.; Wang, H.; Ge, Q. The influence of cross-cultural awareness and tourist experience on authenticity, tourist satisfaction and acculturation in World Cultural Heritage Sites of Korea. Sustainability 2018, 10, 927. [CrossRef]

130. Whang, H.; Yong, S.; Ko, E. Pop culture, destination images, and visit intentions: Theory and research on travel motivations of Chinese and Russian tourists. J. Bus. Res. 2016, 69, 631-641. [CrossRef]

131. Yu, J.Y.; Ko, T.G. A cross-cultural study of perceptions of medical tourism among Chinese, Japanese and Korean tourists in Korea. Tour. Manag. 2012, 33, 80-88. [CrossRef]

132. Fielding, K.; Pearce, P.; Hughes, K. Climbing Ayers Rock: Relating visitor motivation, time perception and enjoyment. J. Tour. Stud. 1992, 3, 49-57.

133. Wright, K.B. Researching Internet-based populations: Advantages and disadvantages of online survey research, online questionnaire authoring software packages, and web survey services. J. Comput. Mediat. Commun. 2005, 10. [CrossRef]

(C) 2020 by the authors. Licensee MDPI, Basel, Switzerland. This article is an open access article distributed under the terms and conditions of the Creative Commons Attribution (CC BY) license (http://creativecommons.org/licenses/by/4.0/). 